\title{
Fractionation and Physicochemical Properties of Pectic Substances Extracted from Grapefruit Peels
}

\author{
Huda Abdallah Mohamed ${ }^{1 *}$ and Babiker El Wassila Mohamed ${ }^{2}$ \\ ${ }^{1}$ Food Industries Research Department, Industrial Research and Consultancy Center, Khartoum North, Sudan \\ ${ }^{2}$ Departmentof Food Science and Technology, University of Khartoum, Sudan
}

\begin{abstract}
The aim of this work was to extract pectic fractions from grapefruit peels. The Alcohol Insoluble Solids (AIS) were prepared from peels and fractionated sequentially with hot distilled water, ammonium oxalate and hot $0.05 \mathrm{HCl}$. Water, oxalate and acidextracted peels pectin were obtained and compared in terms of yield, physicochemical properties and neutral sugars. The results showed that the major part of grapefruit peels pectin was extracted in acid fraction. The water soluble fraction gave higher moisture and ash contents and exhibited higher methoxyl content compared to other fractions. The acid soluble fraction afforded higher degree of esterification, anhydrouronic acid, equivalent weight, intrinsic viscosity and molecular weight. Based on degree of estrification and methoxyl content all fractions can be categorized as high methoxyl pectin. The investigation of neutral sugars using TLC showed that all fractions contained similar sugars arabinose, galactose, rhaminose and xylose. Depending on the result obtained it could be concluded that besides material source, pretreatment procedure, temperature, concentration and extractant type the extraction sequence are critical for best extraction conditions and the yield of pectin.
\end{abstract}

Keywords: Grapefruit; Peel; Fractionation; Characterization; Pectin

\section{Introduction}

Citrus peel and apple pomace are the major raw materials used for the production of commercially acceptable pectins [1]. Other sources such as mango peel [2-4] sugar beet residues [5], sunflower heads [6] and cactus (Opuntia spp.) [7] Have been considered for the extraction of commercial pectins. In Sudan grapefruit (Citrus paradisi) is one of the tropical fruits with an important production (total production of 65000 million metric tons) [8]. Sudanese grapefruit is well known for its large size, excellent quality and good coloration. A productivity as high as 40 tons per hectare is obtained [9]. The post-harvest loss which represents about $22 \%$ of the production is due to a short period of high production associated to a high perishability of the fruit. Processing of grapefruit into jam and upgrading of the byproducts could constitute a way to reduce this loss. Grapefruit peels represent about $16-19 \%$ of the total weight of the fruit [10]. These peels are most of the time thrown into nature or used for animal feeding. They have been reported to be a potential source of pectins [11], fibers [12] and polyphenols. Grapefruit waste contains about $37.5 \%$ pectin, $17.2 \%$ soluble sugars, and 14.3 holocellulose of its dry weight [13]. The pectin composition varies with the source from which it is isolated, as well as with conditions used during isolation and purification. The industrial demand for pectin with varying ability to gel or stabilize fruit and dairy products increases the need for accessing pectin of different types or pectin derivatives with tailored properties [14]

Pectin is a polysaccharide consisting mostly of two moieties. These are homogalacturonan, (1-4) linked, a-Dgalacturonic acid and its methyl ester; and rhamnogalacturonan I, (1-2) repeating linked, a-L-rhamnose-(1-4) a-Dgalacturonic acid disaccharide. Rhamnogalacturonan II contains arabinan, galactan and arabinogalactan side chains. These monosaccharide units comprise most of sugar units found in pectin [15]. Pectin occurs as a white to light brown powder or granular, and odorless or has slightly characteristic odor. According to the FAO [8], pectin is considered to be safe additive that can be taken daily without limits. Pectin have been used in food industry as gelling, thickening and stabilizing agents [16]. The composition, structure and physiological properties of pectin might be influenced by conditions of extraction as well as sources, location and many other environmental factors [17]. Therefore, sequential extraction by using various chemical agents such as EDTA, CDTA, ammonium oxalate, sodium carbonate, sodium hydroxide and hydrochloric acid has generally been used for the fractionation of pectins $[18,19]$. Enzymes and strong acids are also commercially used in the extraction of pectin [20-22].

The extraction of pectin basically involve the aqueous extraction of pectin from the raw material (plant), the isolation of the extracted pectin and purification, followed by drying process. The pectin extraction process should use a suitable method to obtain the maximum yield and quality of pectin. This research work was initiated to evaluate the impact of different extractant on the yield of pectic fractions of grapefruit peels and to investigate their physicochemical properties.

\section{Materials and Methods}

\section{Materials}

Raw material: Fresh grapefruits were purchased from local market three kilogram for each type white and red. The peels were cut into small pieces and dried at $550^{\circ} \mathrm{C}$ in oven for $48 \mathrm{hrs}$ [23]. All the chemicals and reagents were of analytical grade.

\section{Methods}

Proximate chemical analysis: Dry matter was determined by using the method of AOAC [24] by drying samples at $105^{\circ} \mathrm{C}$ for $12 \mathrm{~h}$.

Ash content was determined by measuring the residue remaining after incinerating the sample overnight in a muffle furnace at $600^{\circ} \mathrm{C}$ [25].

*Corresonding author: Huda Abdallah Mohamed, Food Industries Research Department, Industrial Research and Consultancy Center, Khartoum North, Sudan, E-mail: dr.huda6616@yahoo.com

Received May 12, 2015; Accepted May 26, 2015; Published June 02, 2015

Citation: Mohamed HA, Mohamed BEW (2015) Fractionation and Physicochemical Properties of Pectic Substances Extracted from Grapefruit Peels. J Food Process Technol 6: 473. doi:10.4172/2157-7110.1000473

Copyright: (C) 2015 Mohamed HA, et al. This is an open-access article distributed under the terms of the Creative Commons Attribution License, which permits unrestricted use, distribution, and reproduction in any medium, provided the original author and source are credited. 
Protein content was determined by the kjeldahl method then crude protein was calculated by multiplying the $\mathrm{N}$ value with the factor 6.25.

Crude fat was determined by extracted the dried sample with petroleum ether (boiling range $40-60^{\circ} \mathrm{C}$ ) in Soxhlet extraction apparatus for $6 \mathrm{hr}$. The ether extract was filtered in pre-weighed beakers, petroleum ether was evaporated completely from the beakers and the increase in weight of beaker represented the fat (AOAC, 1997).

Crude fiber content was determined by using the method of AOAC [26] samples were digested with $200 \mathrm{ml}(0.225 \mathrm{~N}) \mathrm{H}_{2} \mathrm{SO}_{4}$ acid and 200 $\mathrm{ml}(0.312 \mathrm{~N})$ of $\mathrm{NaOH}$ solutions and the residue calcined. The difference in weight after calcination indicates the quantity of fiber present.

Total carbohydrate (nitrogen free extract) was determined by difference.

All the results were expressed on a dry weight basis. All the experiments in this study were conducted in duplicate.

Determination of Alcohol Insoluble Solids AIS: Alcohol insoluble solids were determined by method described in AOAC (1980) [27]. Twenty grams from each type of grape fruit peels were weighed into a $600 \mathrm{ml}$ beaker then $300 \mathrm{mls}$ of $95 \%$ alcohol were added, stirred, brought to boiling, simmered for $30 \mathrm{~min}$ and then filtered through Buchner fitted with filter paper which was dried previously in a bottomed dish for 2 hours at $100^{\circ} \mathrm{C}$, covered with fit cover and weighed. The residue then washed with $80 \%$ alcohol until washings are clear and colourless. The paper was then transferred to the previous dish and dried at $100^{\circ} \mathrm{C}$ for 2 hours. The final weight minus first weight was recorded as weight of alcohol insoluble solids and its percentage was then calculated as follows:

\section{AIS\% $=$ final weight - first weight $\times 100$ Weight of sample}

Determination of Calcium and Magnesium: The calcium and magnesium were determined by the method of Elmer [28]. One gram of the peel is ignited in a muffle furnace at $500^{\circ} \mathrm{C}$ overnight. The contents were dissolved into $5 \mathrm{ml}$ of $20 \% \mathrm{HCl}$, the solutions were warmed and filtered through acid washed filter paper into $50 \mathrm{ml}$ volumetric flask and made to volume with distilled water. From one milliliter of this solution, the amount of calcium and magnesium were determined spectrophotometrically at wave length of $422.7 \mathrm{~nm}$ and $285.2 \mathrm{~nm}$ respectively using Atomic Absorption Spectrophotometer (3110)

Determination of total pectin: This is carried out according to the method of Luh et al. [29]. Duplicate samples ( 0.1 gm each) of AIS were mixed with $300 \mathrm{ml}$ of 0.05 of the sodium salt of Ethylene Diamine Tetra Acetic Acid (EDTA), treated with $1 \mathrm{~N} \mathrm{NaOH}$ to reach $\mathrm{pH}$ of 11.5, allowed for $30 \mathrm{~min}$ at room temperature and the $\mathrm{pH}$ was adjusted to 5.0 with $1 \mathrm{~N}$ acetic acid. To this mixture, $0.1 \mathrm{gm}$ pectinase was added and stirred for about an hour, diluted to $500 \mathrm{ml}$ with distilled water, filtered through whatman No.1 first few filtrates were discarded. Two milliliters of the filtrate were diluted to $50 \mathrm{ml}$ from which two milliliters were taken for colorimetric determination in spectronic 20 the absorbance of total pectin was measured at wave length $520 \mathrm{~nm}$ with known amount of glacturonic acid ranged from $0.5-3.5 \mathrm{mg} / 2 \mathrm{ml}$.

Preparation of Alcohol Insoluble Solids AIS: Alcohol insoluble solids were prepared according to the method of Luh et al. [29] the grapefruit peels were separated from fruit, sliced into small cubes. The cubes were treated with $400 \mathrm{ml} 95 \%$ ethanol preheated to $70^{\circ} \mathrm{C}$. The mixtures were kept for $10 \mathrm{~min}$ at $70^{\circ} \mathrm{C}$ and were cooled in water bath and mixed in a blender for a minute. Then they were filtered through filter paper No.1 under suction, after which the insoluble materials were washed twice with warm $70 \%$ ethanol to remove sugars and $95 \%$ ethanol at $70^{\circ} \mathrm{C}$ for removing of alcohol-soluble low molecular weight substances and for inactivation of endogenous enzyme system. The alcohol-insoluble solids (AIS) from grapefruit peels, thus obtained were dried at room temperature then ground to pass through 60-mesh and stored at room temperature until use.

Sequential fractionating extraction: Peels pectin fractions were extracted according to the method described by Gordon et al. [30]. One hundred grams sample of the peels AIS were treated with distilled water $\left(\mathrm{dH}_{2} \mathrm{O}\right)$ at a ratio of $1: 3$ at room temperature for $2 \mathrm{~h}$ with continuous stirring and then filtered. Each residue was treated in the same way with $300 \mathrm{ml} \mathrm{dH_{2 }} \mathrm{O}$ for $10 \mathrm{~min}$ and then filtered. The crude filtrates with waterextracted pectin (WEP) were obtained. The insoluble residue from the second water extraction was added to $300 \mathrm{ml}$. $0.75 \%$ ammonium oxalate solution. Two hours extraction was made and the mixture was filtered. The extractions were repeated in the same manner for $10 \mathrm{~min}$. The combined filtrate contained the oxalate extracted pectin (OEP). Both residues were separately further extracted with $300 \mathrm{ml} 0.05 \% \mathrm{HCl}$ for $2 \mathrm{~h}$ at $80^{\circ} \mathrm{C}$ and continuous stirred then filtered. Each residue was treated in the same way with $300 \mathrm{ml} 0.05 \% \mathrm{HCl}$ for $10 \mathrm{~min}$ at $80^{\circ} \mathrm{C}$ and then filtered. The crude filtrates with acid-extracted pectin (AEP) were obtained. The crude extracts of various fractions were precipitated with two volumes cold $95 \%$ ethanol and left for an hour. Water extract pectin (WEP) were coagulated with acidic ethanol $(0.05 \% \mathrm{HCl})$ then left for $12 \mathrm{~h}$. The precipitated crude pectin were separated by filtration, washed once with $100 \mathrm{ml}$ of $80 \%$ ethanol, then with $70 \%$ ethanol to a neutral $\mathrm{pH}$ and finally with $100 \mathrm{ml}$ of acetone. Pectin were dried at $60^{\circ} \mathrm{C}$ in a laboratory dryer ground to pass a60 mesh and kept in separate labeled bottles for further analysis.

\section{Analysis and characterization of pectic fractions}

Analyses were performed at least in duplicates

Determination of ash and moisture contents: The ash content was determined by weighing $1 \mathrm{~g}$ of pectin in a tared crucible and then heated in a muffle furnace at $600^{\circ} \mathrm{C}$ for four hours. The residue was cooled in desiccators and weighed to constant weight. In determining the moisture content, $1 \mathrm{~g}$ of pectin was weighed and dried at $100^{\circ} \mathrm{C}$ for four hours to a constant weight.

Determination of ash alkalinity: The ash was dissolved in $25 \mathrm{ml}$ of $0.1 \mathrm{~N} \mathrm{HCl}$ heated gently and then titrated with $0.1 \mathrm{~N} \mathrm{NaOH}$ using phenolphthalein indicator. Then ash alkalinity calculated as the number of milliliters of acid required neutralizing one gram ash.

Determination of equivalent weight: The determination of methoxyl and AUA contents and the equivalent weight were conducted following the method described by Owens et al. [31]. The values of equivalent weights were used for calculating the anhydrouronic acid (AUA) content and the degree of esterification.

Equivalent weights were determined by weighing $0.5 \mathrm{~g}$ pectin in a $250 \mathrm{ml}$ conical flask and moistening it with $5 \mathrm{ml}$ of ethanol. One gram of sodium chloride was added to sharpen the end point. Free carbon dioxide distilled water $(100 \mathrm{ml})$ and six drops of phenol red indicator were added. The mixture was then stirred rapidly to ensure that all the pectic $\mathrm{NaOH}$ until the color of the indicator changed to pink ( $\mathrm{pH} 7.5$ ) and persisted for at least 30 seconds. The neutralized solution was used for the methoxyl determination. The following equation was used to calculate the equivalent weight: 
Equivalent Weight $=$ Weight of sample $(\mathrm{mg})$

meq. of sodium hydroxide

where

meq. of sodium hydroxide $=$ normality $\mathrm{x}$ titer value

This titer is known as initial titer (IR) or free acid titer.

Methoxyl content: The determination of the methoxyl (MeO) content was performed by adding $25 \mathrm{ml}$ of $0.25 \mathrm{~N} \mathrm{NaOH}$ to the neutralized solution which was shaken thoroughly and allowed to stand for $30 \mathrm{~min}$ at room temperature in a Stoppard flask. Twenty-five milliliters of $0.25 \mathrm{~N} \mathrm{HCl}$ was then added and the mixture was adjusted to $\mathrm{pH} 7.5$ by adding $0.1 \mathrm{~N}$ of $\mathrm{NaOH}$ (titer figure). The following equation was used to calculate the methoxyl content:

Methoxyl content $=\underline{\text { meq. }}$ of $\mathrm{NaOH} \times 31 \times 100$

Weight of sample

Where:

$\mathrm{Meq}$ of $\mathrm{NaOH}=$ normality of $\mathrm{NaOH} x$ titre figure

$31=$ formula weight of methoxyl group.

Anhydrouronic acid (AUA) analysis: By using the values of the equivalent weight and the methoxyl content, the anhydrouronic acid content was calculated from the expression given below:

$(\mathrm{AUA})=\underline{176 \times 100}$

Z

Where $\mathrm{Z}=$ Weight of sample meq. of alkali for free acid + meq. of alkali for methoxyl

$176=$ is the molecular weight of AUA and

Degree of esterification: The degree of estrification was calculated as follows:

Degree of esterification $=\underline{\text { ST } \times 100}$

$$
\mathrm{ST}+\text { corrected IT }
$$

Where $\mathrm{ST}=$ is the saponification titre

IT $=$ is initial titre.

Acetyl content: Acetyl value of pectin samples was determined according the method adopted by Pippen et al. [32]. Pectin samples (0.5 g) were dissolved in $0.1 \mathrm{~N} \mathrm{NaOH}$ solutions with stirring and allowed to stand overnight. The contents were diluted to $50 \mathrm{ml}$ with distilled water and an aliquot $(20 \mathrm{ml})$ was placed into the distillation apparatus. Twenty milliliters magnesium sulphate- sulfuric acid solution (100 g magnesium sulphate and $1.5 \mathrm{~g}$ of sulphuric acid diluted to $180 \mathrm{ml}$ ) were also transferred to distillation apparatus, distilled, and about 100 $\mathrm{ml}$ of distillate was collected. The distillate was titrated with $0.5 \mathrm{~N}$ $\mathrm{NaOH}$ using phenol red indicators. A blank distillation using $20 \mathrm{ml}$ of the magnesium sulphate-sulfuric acid solution was carried out and the distillate was titrated. The acetyl content was calculated according to the following equation:-

\section{Acetyl content $\%=$ net $\mathrm{ml}$ of $\mathrm{NaOH} \times$ normality of $\mathrm{NaOH} \times 4.3$}

\section{Weight of sample $(\mathrm{g})$ in the aliquot}

Determination of neutral sugars: Thin Layer chromatography (TLC) was conducted on a plate $(20 \times 20)$ samples and reference sugars (0.1) were dissolved in $10 \%$ isopropanol and were spotted. The plates were developed by the ascending method using solvent n-butanolacetic acid-distilled water in ratio $(5: 4: 1 \mathrm{v} / \mathrm{v})$. The sugar was detected by spraying the plates with allocating reagent prepared from $(4 \mathrm{gm}$ diphenylamine, $4 \mathrm{ml}$ aniline, $20 \mathrm{ml}$ orthophosphoric acid in $200 \mathrm{ml}$ acetone)as described by Baily and Bourne [31-33].

Viscosity: Viscosity of pectin solution was measured by viscometer (Ostwald-Cannon-Fenske No.1098). Pectin samples (0.1 gm) of each was prepared in $50 \mathrm{ml}$ of distilled water and the $\mathrm{pH}$ was adjusted to 4.8 by $0.1 \mathrm{~N}$ sodium hydroxide. The solution was stirred for $2 \mathrm{~h}$, then 15 $\mathrm{ml}$ of calgon were added and stirred for further hour. The $\mathrm{pH}$ then was adjusted to 6.0 with $0.1 \mathrm{~N}$ acetic acid the solution was completed to 100 mls with distilled water in volumetric flask the viscosity was determined within an hour in room temperature. The efflux time was determined in the same instrument for the solvent of calgon. The relative viscosity was calculated as the ratio of the time of efflux for solution to that of solvent. To determine the intrinsic viscosity another three concentrations $(0.15$, 0.1 and $0.05 \mathrm{~g} / 100 \mathrm{ml}$ ) were prepared as mention before. The relative viscosity was calculated. To get the intrinsic viscosity the ratio $(\mathrm{mr}-1 / \mathrm{c})$ was plotted against $c$ and extrapolated to zero to obtain the intrinsic viscosity

\section{$\mathrm{C}=$ concentration}

$\mu \mathrm{r}=$ relative viscosity

The average molecular weight was determined from intrinsic viscosity data according to the equation:-

$\mathrm{N}=1.4 \times 10^{-6} \mathrm{M}^{1.34}$

Where

$\mathrm{N}=$ intrinsic viscosity

$\mathrm{M}=$ molecular weight

\section{Results and Discussion}

The moisture content of grapefruit peels was $(75.25 \%, 75.37 \%)$ for white and red samples respectively which was in the range of $66-96 \%$ generally for fruit and vegetable and is known to be variable even in the same variety depending upon locality and other environmental factors [34]. The grapefruit peels had ash $(1.5,1.6 \%)$, protein $(1.05,1.15 \%)$ and crude fiber content $(1.73,1.82 \%)$. Quantities of calcium for both types were amounted to $(0.69,0.71)$ and for magnesium $0.17 \mathrm{mg} / 100 \mathrm{gm}$ for both type respectively (Table 1 ). The AIS obtained from red fresh peels was $9.5 \mathrm{~g} / 100$, while $10.5 \mathrm{~g} / 100 \mathrm{~g}$ from white fresh peels. The AIS taken from grapefruit peels contained $(7.01,7.17 \%)$ moisture, $(3.27,3.37 \%)$ ash, $(0.06,0.08 \%)$ protein, $(1.83,1.04 \mathrm{mg} / 100 \mathrm{gm})$ calcium, $(0.17,0.19$ $\mathrm{mg} / 100 \mathrm{gm})$ magnesium with total pectin amounted to 25.00 and $25.26 \%$, lignin was $(0.08,0.09 \%)$ for red and white samples respectively (data not shown). The AIS was fractionated by sequential extraction, resulting in obtaining 3 pectic substance fractions such as WEP, OEP and AEP. In our study we obtained $(6.38,8.20)$ water pectin, $(5.23$, $6.92)$ oxalate pectin and $(7.80,11.20)$ acid pectin for the red and white types (Table 2). This result showed that the major part of grapefruit peel pectin is extracted in the acid fraction. Yapo et al. [35] carried out sequential fractionating extraction from AIS of industrial citrus peels (1:30 AIS: extractant) with $\mathrm{dH}_{2} \mathrm{O}$, oxalate, hot $\mathrm{HCl} 0.05 \mathrm{M}$, and cold $0.05 \mathrm{M} \mathrm{NaOH}$. They obtained $5.8 \mathrm{~g} / 100 \mathrm{~g}$ AIS water extracted pectin and $27.3 \mathrm{~g} / 100 \mathrm{~g}$ AIS acid extracted pectin. In Georiev et al. conducted sequential fractionating on orange and lemon peels they obtained 10.94 $\mathrm{g}$ and $16.3 \mathrm{~g}$ water extracted orange and lemon peels pectin per $100 \mathrm{~g}$ AIS, and $18.44 \mathrm{~g}$ and $18.00 \mathrm{~g}$ acid extracted orange and lemon pectin 


\begin{tabular}{|l|c|c|}
\hline \multirow{2}{*}{ Parameters (\%) } & \multicolumn{2}{|c|}{ Grapefruit Peels Type } \\
\cline { 2 - 3 } & Peels of White Type & Peels of Red Type \\
\hline Moisture & 75.25 & 75.37 \\
\hline Ash & 1.50 & 1.60 \\
\hline Protein & 1.05 & 1.15 \\
\hline Oil & 0.20 & 0.40 \\
\hline Fiber & 1.73 & 1.82 \\
\hline Carbohydrate (by difference) & 20.27 & 19.66 \\
\hline Reducing sugars & 10.4 & 10.2 \\
\hline Alcohol Insoluble Solids(AIS) & 10.5 & 9.5 \\
\hline Calcium mg/100g & 0.69 & 0.71 \\
\hline Magnesium mg/100g & 0.17 & 0.17 \\
\hline
\end{tabular}

Each value is a mean of duplicate determinations

Table 1: Components of Grapefruit Peels

\begin{tabular}{|l|c|c|}
\hline \multirow{2}{*}{ Parameters (\%) } & \multicolumn{2}{|c|}{ Grapefruit Peels Type } \\
\cline { 2 - 3 } & Peels of White Type & Peels of Red Type \\
\hline Water Soluble Pectin & 8.20 & 6.38 \\
\hline Ammonium Oxalate Soluble Pectin & 6.92 & 5.23 \\
\hline Acid Soluble Pectin & 11.20 & 7.80 \\
\hline
\end{tabular}

Table 2: Pectin Content of Water, Oxalate and Acid Fractions

\begin{tabular}{|l|c|c|}
\hline \multirow{2}{*}{ Parameters (\%) } & \multicolumn{2}{|c|}{ Water Soluble Pectin } \\
\cline { 2 - 3 } & White Type & Red Type \\
\hline Moisture & 8.21 & 8.35 \\
\hline Ash & 11.05 & 7.05 \\
\hline Ash Alkalinity & 2.26 & 2.05 \\
\hline Methoxyl Content & 7.50 & 8.04 \\
\hline Acetyl Content & 0.55 & 0.52 \\
\hline Degree of Esterification & 52.03 & 53.23 \\
\hline Equivalent Weight & 298.000 & 305.000 \\
\hline Anhydrouronic acid(AUA) & 31.8 & 31.8 \\
\hline Protein & 0.06 & 0.07 \\
\hline Intrinsic Viscosity & 1.5 & 1.5 \\
\hline Molecular Weight $\times 10^{4}$ & 3.126 & 3.126 \\
\hline Calcium mg/100g & 0.39 & 0.36 \\
\hline Magnesium mg/100g & 0.005 & 0.005 \\
\hline
\end{tabular}

Each value is a mean of duplicate determinations

Table 3: Properties of Water Soluble Pectic Fraction

per $100 \mathrm{~g}$ AIS. Comparing above mentioned results with those obtained in this study, it could be concluded that besides material source and pretreatment procedure the extractant type, temperature, concentration and extraction sequence are critical for best extraction conditions.

\section{Analysis and characterization of pectic fractions}

The water soluble fraction gave higher moisture $(8.21 \%, 8.35 \%)$ and ash $(11.05 \%, 7.05 \%)$ contents compared to the oxalate fraction $(8.20 \%, 7.75 \%)$ moisture and $(5.7 \%, 4.4 \%)$ ash which ranked secondly and the acid fraction which had lower moisture $(6.20 \%, 5.22 \%)$ and ash contents for white and red respectively, the results presented in Tables 3-5). These results agree well with findings of El shafie [36] for pumpkin pectic fractions who reported $(8.6 \%, 7.3 \%, 6.8 \%)$ for water soluble fraction, $(3.3 \%, 3.4 \%, 3,5 \%)$ for oxalate soluble fraction and acid fraction which gave lower ash content $(3.1 \%, 3.2 \%, 3.3 \%)$. Also results supported by the highest value of ash alkalinity-measure of mineral constituent combined with organic groups-for water soluble fraction with value up to $2.26 \mathrm{meq} \mathrm{NaOH} / \mathrm{gm}$ for white type. The maximum limit of ash for good gel formation and good pectin quality is $10 \%$. Pectin should have as low as moisture content as possible for safe storage and to inhibit the growth of microorganism that can affect the pectin quality due to the production of pectinase enzyme. The difference in moisture content of different pectic fractions could be due to the difference in hygroscopic nature of pectin with different degree of esterification. The water soluble fraction had highest methoxyl content $(7.50 \%, 8.04 \%)$ compared to other fractions. This compatible with findings of El shafie [36] who obtained $(5.42 \%, 5.69 \%),(4.49 \%, 4.68 \%)$ and $(4.09 \%$, $4.25 \%)$ for water oxalate and acid fractions respectively. Generally the water soluble fraction consists of substances of high methoxyl content [37]. The results indicated the acid soluble fraction ranked first in the degree of esterification $(57.54 \%, 56.56 \%)$ followed by oxalate soluble fraction $(53.26 \%, 55.34 \%)$ and water soluble fraction had lower value $(52.03 \%, 53.23 \%)$. This result is in contrast with findings of El shafie [36] who reported high degree of esterification for water soluble fraction followed by oxalate and acid fractions respectively. The degree of esterification for all fractions was above 50\% indicating that the fractions were characterized as high methoxyl pectin. The equivalent weights obtained were used in the calculations of the \% AUA and $\%$ DE. The acid soluble fraction gave high value of equivalent weights $(1041.00,1428.00)$ followed by oxalate $(819.000,1250.000)$ and lower value $(298.000,305.000)$ for water fractions for both type respectively. The differences in equivalents weight between the fractions might be due to the variability in non uronide materials [38]. The content of AUA indicates the purity of the extract pectin and suggested to be not less than $65 \%$ [39]. However, the AUA obtained under all extraction conditions

\begin{tabular}{|l|l|l|}
\hline \multirow{2}{*}{ Parameters (\%) } & \multicolumn{2}{|c|}{ Oxalate Soluble Pectin } \\
\cline { 2 - 3 } & White Type & Red Type \\
\hline Moisture & 8.20 & 7.75 \\
\hline Ash & 5.70 & 4.40 \\
\hline Ash Alkalinity & 1.56 & 1.42 \\
\hline Methoxyl Content & 6.8 & 5.84 \\
\hline Acetyl Content & 0.20 & 0.20 \\
\hline Degree of Esterification & 53.26 & 55.34 \\
\hline Equivalent Weight & 819,000 & 1250,000 \\
\hline Anhydrouronic acid(AUA) & 30.40 & 27.70 \\
\hline Protein & 0.08 & 0.07 \\
\hline Intrinsic Viscosity & 2.50 & 2.50 \\
\hline Molecular Weight $\times 10^{4}$ & 4.677 & 4.677 \\
\hline Calcium mg/100g & 0.08 & 0.15 \\
\hline Magnesium mg/100g & 0.01 & 0.02 \\
\hline
\end{tabular}

Each value is a mean of duplicate determinations

Table 4: Properties of Ammonium Oxalate Soluble Pectic Fraction

\begin{tabular}{|l|c|c|}
\hline \multirow{2}{*}{ Parameters (\%) } & \multicolumn{2}{|c|}{ Acid Soluble Pectin } \\
\cline { 2 - 3 } & White Type & Red Type \\
\hline Moisture & 6.20 & 5.22 \\
\hline Ash & 4.20 & 4.40 \\
\hline Ash Alkalinity & 1.14 & 0.62 \\
\hline Methoxyl Content & 3.07 & 2.45 \\
\hline Acetyl Content & 0.61 & 0.60 \\
\hline Degree of Esterification & 57.54 & 56.56 \\
\hline Equivalent Weight & 1041,00 & 1428,00 \\
\hline Anhydrouronic acid(AUA) & 33.9 & 36.04 \\
\hline Protein & 0.13 & 0.09 \\
\hline Intrinsic Viscosity & 2.0 & 3.25 \\
\hline Molecular Weight $\times 10^{4}$ & 3.981 & 6.310 \\
\hline Calcium mg/100g & 0.09 & 0.07 \\
\hline Magnesium mg/100g & 0.02 & 0.01 \\
\hline
\end{tabular}

Each value is a mean of duplicate determinations

Table 5: Properties of Acid Soluble Pectic Fraction. 


\begin{tabular}{|l|c|c|c|c|c|}
\hline Samples & AUA & Arabinose & Galactose & Xylose & Rhamnose \\
\hline Water soluble pectin & & & & & \\
\hline Red type & 31.80 & $*$ & $*$ & $*$ & $*$ \\
\hline White type & 31.80 & $*$ & $*$ & $*$ & $*$ \\
\hline Oxalate soluble pectin & & & & & \\
\hline Red type & 27.70 & $*$ & $*$ & $*$ & $*$ \\
\hline White type & 30.40 & ${ }^{*}$ & $*$ & $*$ & $*$ \\
\hline Acid soluble pectin & & & & & \\
\hline Red type & 36.04 & $*$ & $*$ & $*$ & $*$ \\
\hline White type & 33.90 & $*$ & $*$ & $*$ & $*$ \\
\hline
\end{tabular}

*indicates presence of the sugar

Table 6: Sugars separated by partial acid hydrolysis of pectic fractions.

was less than $65 \%$ this indicates the extract may not be sufficiently pure due to the possible presence of proteins, starch and sugars in precipitated pectin. The acid soluble fraction showed high $(36.4 \%, 33.90 \%)$ AUA followed by water soluble fraction $(31.8 \%, 31.8 \%)$ and finally the oxalate soluble fraction $(30.4 \%, 27.7 \%)$. It was evident from the data generated on the acid soluble fraction higher purity comparable to other fractions, as higher AUA and lower ash content are the two criteria governing the purity of pectin [40]. The same pattern was appearing in the results of protein content in all fractions the acid gave higher protein content $(0.13 \%, 0.09 \%)$ followed by oxalate $(0.08 \%, 0.07 \%)$ and finally the water fraction $(0.06 \%, 0.07 \%)$, coinciding with findings of El shafie [36]. The acetyl content was found to give higher score $(0.61 \%, 0.60 \%)$ for acid fractions followed by water fractions which recorded $(0.55 \%, 0.52 \%)$ and the lower value obtained by oxalate fractions $(0.20 \%, 0.20 \%)$ for red and white types respectively. Ranganna [41] reported that the gelling capacity of pectin decreased with increase in the degree of acetylation. If acetyl group is present in pectin, it inhibits jell formation. Schultz [42] reported that samples containing 3.5\%-4.0\% acetyl gives weak gels while gelling power restored at levels around $2.4 \%$ acetyl. The acid soluble fraction realized high intrinsic viscosity $(2.5-3.25 \mathrm{dl} / \mathrm{g})$ followed by oxalate $(2.5 \mathrm{dl} / \mathrm{g})$ and finally water $(1.5 \mathrm{dl} / \mathrm{g})$ for red and white types respectively. The results are in agreement with findings of El shafie [36] who reported high value of intrinsic viscosity for acid and lower value of intrinsic viscosity for water soluble fraction. It is possible that the acid fraction was composed of molecules of originally high molecular weight and that part of the abundant calcium in these fractions is in the adsorbed form [43]. The acid soluble fraction contained (0.07-0.09) $\mathrm{mg} / 100 \mathrm{~g}$, while oxalate $(0.08-0.15) \mathrm{mg} / 100 \mathrm{~g}$ and water contained (0.36-0.39) $\mathrm{mg} / 100 \mathrm{~g}$ calcium and this explains the high ash content and high ash alkalinity in this fraction. Since the intrinsic viscosity is a function of a molecular weight, the highest values for molecular weight were recorded for the acid soluble fraction as shown in Table 5.

\section{Sugar composition of pectic fractions}

The investigation of neutral sugars using TLC showed that all fractions contained similar sugars arabinose, galactose, rhaminose and xylose together with galactouronic acid (Table 6). The presence of sugars also confirmed by McCready and Gee [44] El shafie [36] Koubala et al. $[45,46]$ and Georgiev et al. [47].

\section{Conclusion}

Pectin was successfully extracted from grapefruit peels. Three different fractions were obtained after sequential fractionating, extraction with hot water, ammonium oxalate and diluted $\mathrm{HCl}$. The $\mathrm{HCl}$ appeared to be the most effective extractant in solubilizing and releasing pectin from grapefruit peels compared to other extractant. The pectin extracted by acid has higher purity as compared to the water and ammonium oxalate pectin fractions. However, the data obtained showed that extractant have important effects on the features of extracted pectic fractions of two types of grapefruit peels. The ability of individual pectic fraction to form gel is dependent on level of present galacturonic acid in extract in addition to the composition and structure of extracted pectic fractions. The pectic fractions extracted by different extractants were highly methylated, (more than 50\%) which indicates their suitability in the food industries as thickening agent and stabilizer. The exploitation of grapefruit peels as a source of functional compounds and their application in food is a promising field requires inter disciplinary research of food technologists, food chemists, nutritionists and toxicologists. In the near future, we are challenged to respond to this research results.

\section{References}

1. May CD (1990) Industrial pectins: Sources, production and applications Carbohydrate Polymers, 12: 79-99.

2. Berardini N, Fezer R, Conrad J, Beifuss U, Carle R, et al. (2005) Screening of mango (Mangifera indica L.) cultivars for their contents of flavonol O- and xanthone $\mathrm{C}$ glycosides, anthocyanins, and pectin. Journal of Agricultural and Food Chemistry 53: 1563-1570.

3. Berardini N, Knodler M, Schieber A, Carle R (2005) Utilisation of mango peels as source of pectin and polyphenolics. Innovative Food Sci. Emerging Technol 6: 442-452.

4. Kratchanova M, Benemou C, Kratchanova C (1991) On the pectic substances of mango fruits. Carbohydrate Polymers 15: 271-282.

5. Levigne S, Ralet MC, Thibault JF (2002) Characterization of pectins extracted from fresh sugar beet under different conditions using an experimental design. Carbohydrate Polymers 49: 145-153.

6. Alistair M. Stephen, Glyn O. Phillips (1995) Food polysaccharides and their applications. CRC Press, New York.

7. Goycoolea FM, Ca' rdenas A (2003) Pectins from Opuntia spp. A short review. Journal of the Professional. Association for Cactus Development, 5: 17-29.

8. FAO (1969) Nutrition meetings of the FAO

9. Khalil MI (1984) Growth, Yield Potential and Quality Attributes of Thirteen Grapefruit Cultivars in Central Sudan. M.Sc. Thesis, University of Gezira, Wad Medani, Sudan.

10. Kansci G, Koubala BB, Lape MI (2003) Effect of ripening on the composition and the suitability for jam processing of different varieties of mango (Mangifera indica). African Journal of Biotechnology 2: 301-306.

11. Pedroza-Islas, Aguilar-Esperanza RE, Vernon-Carter EJ (1994) Obtaining pectins from solid wastes derived from mango (Mangifera indica) processing AIChE Symp Ser 300: 36-41.

12. Larrauri JA, Ruperez $P$, Borroto B, Saura-Calixto $F$ (1996) Mango peels as a new tropical fibre: Preparation and characterization. Lebensmittel-Wissenschaft und-Technologie 29: 729-733.

13. Kabli SA, Garni SM (2006) Bioextraction of Grapefruit Pectin by Kluyveromyces Marxianus. Research Journal of BioTechnology 1: 10-16.

14. Rosenbohm C, Lundt I, Christensen TMIE, Young NWG (2003) Chemically methylated and reduced pectins: preparation, characterisation by $1 \mathrm{H}$ NMR spectroscopy, enzymatic degradation and gelling properties. Carbohydr Res 338: 637-649.

15. Joye DD, Luzio GA (2000) Process for Selective Extraction of Pectins from Plant Material by Different pH. Carbohydrate Polymers 43: 337-342.

16. King K (1993) Pectin: Untapped natural resource. Food Science and Technology Today, 3: 147-152

17. Perez S, Mazeau K, Penhoat $\mathrm{CH}$ (2000) The three-dimensional structures of the pectic polysaccharides. Plant Physiology and Biochemistry 38: 37-55.

18. Eriksson I, Andersson R, Aman P (1997) Extraction of pectic substances from dehulled rapeseed. Carbohydrate Research 301: 177-185.

19. Yakushiji H, Sakurai N, Morinaga K (2001) Changes in cellwall polysaccharides 
Citation: Mohamed HA, Mohamed BEW (2015) Fractionation and Physicochemical Properties of Pectic Substances Extracted from Grapefruit Peels. J Food Process Technol 6: 473. doi:10.4172/2157-7110.1000473

from the mesocarp of grape berries during veraison. Physiologia Plantarum 111: 188-195.

20. Whistler RL, BeMiller JN (1997) Pectins. Carbohydrate chemistry for food scientists. St. Paul, MN: Eaga Press.

21. Shkodina OG, Zeltser OA, Selivanov NY, Ignatov VV (1998) Enzymic extraction of pectin preparations from pumpkin. Food Hydrocolloids 12: 313-316.

22. Kalapathy U, Proctor A (2001) Effect of acid extraction and alcohol precipitation conditions on the yield and purity of soy hull pectin. Food Chemistry 73: 393396

23. Arslan N, Togrul H (1996) Filtration of pectin extract from grapefruit peel and viscosity of pectin solutions. Journal of Food Engineering 27: 191-201.

24. AOAC (1997) Official Methods of Analysis. AOAC International, Maryland.

25. AOAC (1984) Official methods of analysis, Association of Official Analytical Chemists, Washington DC.

26. AOAC (1975) Official Methods of Analysis. Association of Official Analytical Chemistry, Washington DC.

27. AOAC (1980) Official Methods of Analysis. 13th ed, Washington DC.

28. Elmer (1993) Handbook of Atomic Absorption Spectrophotometer

29. Luh BS, Postlmyer HS, Leonard SJ (1960) Chemical and colour changes in canned tomato ketchup. Food Technol 15: 52.

30. Gordon LP, Brown HD, Gould WA, Rees BD (1954) Effect of added calcium and sodium hexametaphosphate on the pectin content and viscosity of tomato puree. J Food Technol 8: 221-225.

31. Owens HS, McCready RM, Shepherd AD, Schultz SH, Pippen EL, et al. (1952) Methods used at Western Regional Research Laboratory for Extraction and Analysis of Pectic Materials 340: 1-33.

32. Pippen EL, McCready RM, Owens S (1950) Determination of acetyl in pectin Analy Chem 22: 1457-1459.

33. Bailey RW, Bourne EJ (1960) Separation of sugars by Thin Layer Chromatography. J Chromatogr A 34: 116-120.

34. Rui MS Cruz, Igor Khmelinskii, Margarida Vieira (2014) Methods in food analysis. CRC Press, New York.
35. Yapo BM, Robert C, Etienne I, Wathelet B, Paquot M (2007) Effect of extractions on the yield, purity and surface properties of sugar beet pulp pectin extracts. Food chemistry 100: 1356-1364.

36. El-Shafie AS (1981) Isolation, fractionation and characterization of pumpkin pectic substances. M.Sc. thesis, University of Khartoum.

37. McCready RM, McComb,EA (1952) Extraction and determination of pectic substances. Anal Chem 24: 1986-1988.

38. McCready RM (1970) Pectin. Methods in Food Analysis. Academic Press, New York, London.

39. Food Chemical Codex (1996) IV monographs. National Academy Press, Washington DC.

40. Hwang J, Roshdy TH, Kontominas M, Kokini JL (1992) Comparison of dialysis and metal precipitation effects on apple pectin. J Fd Set 57: 1180-1184.

41. Ranganna S (2002) Hand book of Analysis and quality control for fruit and vegetable products. Second edition. Tata McGraw-Hill publishing company Ltd., USA.

42. Schult TH (1965) Methods in charbohydrate chemistry. Academic press. Inc 5:167-194

43. Bettlheim FA, Sterling C (1955) Factors associated with potato texture and pectic substance. Food Res 20: 118-129.

44. McCready RM, Gee MJ (1960) Plant pectin analysis, determination of pectic substances by paper chromatography. J Agr Food Chem 8: 510-513.

45. Koubala BB, Kansci G, Mbome LI, Crepeau MJ, Thibault JF, et al. (2008) Effect of extraction conditions on some physicochemical characteristics of pectins from "Améliorée" and "Mango" mango peels. Food Hydrocolloids 22: 13451351.

46. Koubala BB, Mbome LI, Kansci G, Mbiapo FT, Crepeau MJ, et al. (2008) Physicochemical properties of pectins from ambarella peels (Spondia cytherea) obtained using different extraction conditions. Food Chemistry 106: 1202-1207.

47. Georgiv Y, Ognyanov M, Kussovski V, Kratchanova M (2012) Isolation, characterization and modification of citrus pectins. Jounal of BioScience and Biotechnology 1: 223-233. 